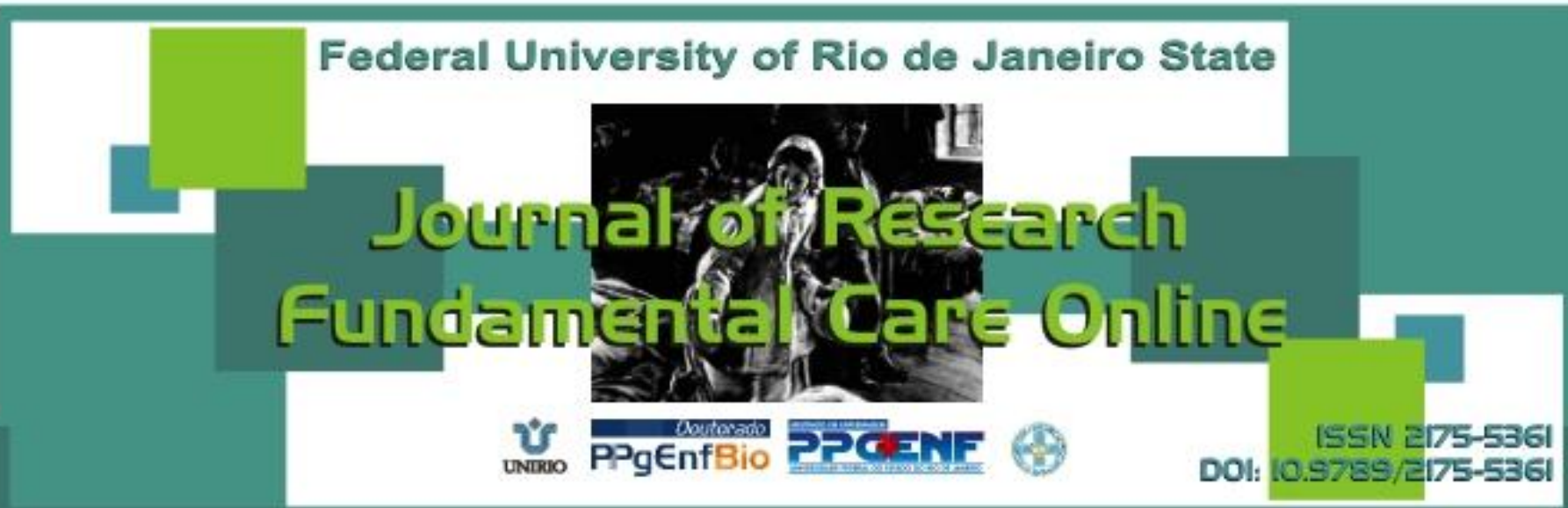

\title{
INTEGRATIVE REVIEW OF LITERATURE
}

\section{Funcionalidade em idosos: produção de conhecimento na última década}

Functionality in the elderly: knowledge production in the last decade

Funcionalidad en las personas mayores: la producción de conocimiento en la última década

Sônia Mara Gusmão Costa ${ }^{1}$, Tatyanni Peixoto Rodrigues² ${ }^{2}$ Kiara Maria Vieira Pinto ${ }^{3}$, Olívia Galvão Lucena Ferreira ${ }^{4}$, Maria Adelaide Silva Paredes Moreira ${ }^{5}$, Antonia Oliveira Silva ${ }^{6}$ \begin{abstract}
Objective: discussing the scientific production on health about the functional capacity of the elderly through an integrative literature review of the last ten years. Method: an integrative review was used, since this method allows for searching, critical evaluation and synthesis of the available evidence from the research theme, being its final product the current state of knowledge and identifying gaps that drive development of future research. Results: starting the process of defining descriptors, it used the operator "terminology in health" where it identified terms relevant to their studies as descriptors: Functionality and Elderly; being able to selecting 13 articles that met the inclusion and exclusion criteria. Conclusion: through the characterization of the analyzed reports, it believes that Brazilian articles on health that punctuate Functionality in the Elderly in daily activities, demonstrate that this field is not yet saturated. Descriptors: Elderly, Health, Functionality.
\end{abstract}

RESUMO

Objetivo: discutir a produção científica na área da saúde acerca da capacidade funcional de idosos, através de uma revisão integrativa da literatura dos últimos dez anos. Método: foi utilizada a revisão integrativa, visto que este método permite a busca, a avaliação crítica e a síntese das evidências disponíveis do tema investigado, sendo o seu produto final o estado atual desse conhecimento, bem como a identificação de lacunas que direcionam para o desenvolvimento de futuras pesquisas. Resultados: partindo do processo de definição dos descritores, utilizou-se o operador "terminologia em saúde" onde se identificou termos relevantes para os estudos como os descritores: Funcionalidade e Idoso. Podendo-se selecionar 13 artigos que atenderam aos critérios de inclusão e exclusão. Conclusão: pela caracterização das publicações analisadas, consideramos que os artigos brasileiros, na área da saúde que pontuam a Funcionalidade em Idosos nas atividades cotidianas, demonstram que este campo ainda não está saturado. Descritores: Idoso, Saúde, Funcionalidade.

RESUMEN

Objetivo: analizar la producción científica acerca de la salud sobre la capacidad funcional de las personas mayores a través de una revisión integradora de la literatura de los últimos diez años. Método: es una revisión integradora, ya que este método permite la búsqueda, evaluación crítica y síntesis de la evidencia disponible de tema de investigación y su producto final, el estado actual del conocimiento y la identificación de los vacíos que impulsan el desarrollo de futuras investigaciones. Resultados: al iniciar el proceso de definición de descriptores, se utilizó el operador "terminología en la salud" donde identificó términos relevantes para sus estudios como descriptores: Funciones y Ancianos, Siendo capaz de seleccionar 13 artículos que cumplieron los criterios de inclusión y exclusión. Conclusión: por la caracterización de los informes analizados, creemos que los artículos brasileños en la salud que marcan la funcionalidad de las personas mayores en las actividades diarias demuestran que este campo aún no está saturado. Descriptores: Edad avanzada, La salud, La funcionalidad.

${ }^{1}$ Physiotherapist, Master of the Postgraduate Program of Nursing/ UFPB, Member of the International Group of Studies and Researches on Aging and Social Representations - GIEPERS. João Pessoa (PB), Brazil. Email: sonia.gusmaocosta@yahoo.com.br. ${ }^{2}$ Nurse, Doctoral student of the Postgraduate Program of Nursing/ UFPB, GIEPERS member. João Pessoa (PB), Brazil. Email: tatchy.rodrigues@hotmail.com. ${ }^{3}$ Physiotherapist, Masters' student at PPGENF/UFPB, Specialist, GIEPERS member. João Pessoa (PB), Brazil. Email: kiaravieira@dr.com. ${ }^{4}$ Physiotherapist, Lecturer at the College of Medical Sciences of Paraiba, Doctoral student of the Postgraduate Program of Nursing/UFPB, GIEPERS member. João Pessoa (PB), Brazil. E-mail: oliviaglf@hotmail.com. ${ }^{5}$ Physiotherapist, Doctorate, Professor at the Postgraduate Program of Nursing, UFPB/PNPD/Capes, GIEPERS member. João Pessoa (PB), Brazil. Email: jpadelaide@hotmail.com. ${ }^{6}$ Nurse, PhD, Professor at the Postgraduate Program of Nursing/UFPB, GIEPERS leader. João Pessoa (PB), Brazil. Email: alfaleda@hotmail.com. 


\section{INTRODUCTION}

ging is a process that involves particular hereditary factors, the action of the environment, diet, type of occupation and lifestyle, as well as the social context. It is an evolutionary phenomenon marked by specific changes correlated with the passage of time. ${ }^{1,2}$

With the arrival of old age; changes occur, including the weakening of muscle tone and bone formation, which may lead to a change in the posture of the trunk and lower extremities, accentuating the curvature of the thoracic and lumbar spine. In addition, the joints become more stiff, reducing the movements and producing changes in balance and gait. ${ }^{3}$ There are also alterations in the protective reflexes and balance control, thereby impairing the body mobility and, thus, predisposing the occurrence of risk of falls and fractures, causing serious consequences on the functional performance. ${ }^{3,4,5}$

Functional capacity refers to the capability to performing activities of daily living (ADLs) or to performing certain act without help, covering two types of activities, basic and instrumental. ${ }^{5}$ Possessing or not functional capacity influences completely on quality of life of elderly. ${ }^{6}$ The impaired functional capacity of the elderly has important implications for the family, the community, the health system and for the life of the elderly, as this causes more vulnerability and dependency in old age, contributing to the decrease of welfare. ${ }^{3,6}$

The basic activities of daily living (BADL) consist of self-care tasks such as bathing, dressing and feeding and are based on the Katz index. ${ }^{6}$ This measure reflects a substantial level of incapacity. ${ }^{6}$ In general, the greater the number of problems a person has with BADL, the more severe is their inability. ${ }^{6,7}$ The prevalence of difficulty or need of help in performing BADL is lower than the prevalence of other measures of functional disability. ${ }^{7}$

Instrumental activities of daily living (IADL) are skills of the elderly to managing the environment in which it lives, including preparing meals, doing housework, washing, handling money, using the telephone, taking medications, shopping and using the ways of transport. ${ }^{8}$

However the term functionality encompasses all functions of the body and the individual's ability to performing activities and tasks relevant to the daily routine, as well as their participation in society. ${ }^{9}$

Starting from these considerations it justifies our interest in developing an integrative review of the scientific production in health about the functional capacity of the elderly in the last ten years to recognizing the profile of these publications. Once the health status of the elderly has not been evaluated only by the presence or absence of disease, but also by the level of preservation of their functionality. ${ }^{10}$ 


\section{METHOD}

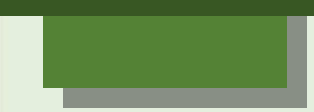

It opted to performing this study the use of the integrative review method, since this allows the search, critical evaluation and synthesis of the available evidence from research theme, and its end product is the current state of that knowledge, as well as identifying gaps that lead to the development of future researches ${ }^{11}$.

For the development of an integrative review steps should be followed carefully, they are: 1. selection of hypotheses; 2 . selection of the research that will compose the review sample; 3 . defining characteristics of primary research that comprise the review sample; 4. interpretation of results; 5 . account of revision providing a critical examination of findings ${ }^{11,12}$.

The literature survey of this review was conducted in December 2012 by the Internet, the Virtual Health Library (BVS BRAZIL), and the databases of the source of health sciences in general as (LILACS) Latin American and Caribbean Health Sciences, Scientific Electronic Library Online (SciELO).

Starting from the definition of process descriptors, it used the operator "health terminology" which identified relevant terms for the studies as descriptors: << Functionality $>>$ and $<<$ Elderly $>>$. The inclusion criteria used for the selection of the samples were in full text; in Portuguese; published between the years 2001/2011; published in the databases mentioned. Exclusion criteria contemplated: jobs that do not involve the elderly; jobs that did not focus on the theme "functionality in the elderly"; studies that were not achieved in full; articles of integrative and systematic review.

It was developed and applied a tool for data collection called Registration Form, which was completed for each article of the final sample, allowing to obtain such information: (1) year of publication; (2) the region where the study took place; (3) type of study; (4) objective of the study; (5) footprint, and (6) theme approached; later proceeded to quantitative data analysis, which were organized in spreadsheets in Microsoft Office Excel 2007. The results were expressed by numerical representations, following the systematic distribution by simple frequency, using absolute values and percentages in the table. The discussion was held in the light of literature.

It was not necessary to submit the research project to the Ethics Committee for Research because secondary data have been used in the public domain. 


\section{RESULTS AND DISCUSSION}

Made the search, 69 articles were found making use of the Boolean indicator "and" for the inclusion of all descriptors. $<<$ Functionality $>>$ and $<<$ Elderly $>>$. With the use of the criteria for inclusion and exclusion the research resulted in a total of 13 articles. This result highlights that scientific work encompasses the functionality and the elderly have little representation in databases LILACS and SciELO.

Regarding the geographic source of the selected scientific production was $100 \%$ held by Brazilian researchers. The pattern of production, according to the Brazilian region showed higher concentration in the Southeast region of the country, represented by $53,8 \%$. The South, Midwest and Northeast regions showed 15,34\% of searches, the absence of such research being observed in the northern region, as shown in Table 1 below.

Table 1. Production of knowledge about the functional capacity in older adults in the last decade, as regions of the country.

\begin{tabular}{c|c|c}
\hline Brazilian Regions & $\mathrm{n}$ & $\mathrm{f}(\%)$ \\
\hline Northeast & 2 & 15,34 \\
\hline Southeast & 7 & 53,8 \\
\hline Midwest & 2 & 15,34 \\
\hline South & 2 & 15,34 \\
\hline Total & 13 & 100 \\
\hline
\end{tabular}

Source: Research data.

With regard to the question of publication year, our sample is very current. Inclusion criteria included articles published from 2001 to 2011. But we showed that $53,8 \%$ of the publications occurred in the year 2010. In 2007, 2009 and 2010 we obtained 15,4\% respectively.

Within the science of health, the area that most published on the studied subject was Physiotherapy (38,46\%), followed by Nursing $(23,07 \%)$, Gerontology and Geriatrics $(23,07 \%)$, Occupational Therapy and Physical Education (7,7\%) each.

On the topic the authors of the articles that make up the sample made crosses with the theme functionality, among them were the most commonly used functionality and institutionalization, functionality and diseases (Alzheimer's and diabetes) and falls. The goals addressed mostly the evaluation functionality and functional capacity, physical performance, mobility and factors that may be associated with changes or not arising from the aging process. The comparison and relational analysis was also a widely used objective. As for the type of study methodology the most found type of study was the cross; as can be seen above in Tables 1 and 2. 
Table 1. Distribution of articles categorized according to: Theme, Goal and Methodology. Joao Pessoa PB, 2011.

\begin{tabular}{|c|c|c|}
\hline Theme & Objective & Methodology \\
\hline $\begin{array}{c}\text { Physical capacity } \\
\text { and Falls }\end{array}$ & $\begin{array}{c}\text { Evaluating physical performance in older adults } \\
\text { who engage in physical activity regularly and in } \\
\text { sedentary, comparing groups. }\end{array}$ & Cross-section \\
\hline $\begin{array}{c}\text { Functional capacity } \\
\text { and Alzheimer's }\end{array}$ & $\begin{array}{c}\text { Assess functional capacity, mobility and } \\
\text { cognitive function of elderly people with } \\
\text { Alzheimer's. }\end{array}$ & $\begin{array}{c}\text { Observational } \\
\text { Study }\end{array}$ \\
\hline $\begin{array}{c}\text { Cognition and } \\
\text { physical activity }\end{array}$ & $\begin{array}{c}\text { Checking the correlation between the reaction } \\
\text { time and the cognitive state of elderly } \\
\text { practitioners of physical activities. }\end{array}$ & Case Study \\
$\begin{array}{c}\text { performanctional } \\
\text { Hip Arthroplasty }\end{array}$ & $\begin{array}{c}\text { Compare the gait parameters and functional } \\
\text { performance of elderly with and without total } \\
\text { hip arthroplasty. }\end{array}$ & $\begin{array}{c}\text { Cross-sectional } \\
\text { study }\end{array}$ \\
\hline $\begin{array}{c}\text { Functionality and } \\
\text { Diabetes }\end{array}$ & $\begin{array}{c}\text { Comparing elderly with and without type 2 } \\
\text { diabetes as for functional mobility, to the risk of } \\
\text { falls and the Executive function and check the } \\
\text { correlation between these variables. }\end{array}$ & $\begin{array}{c}\text { Cross-sectional } \\
\text { study, exploratory } \\
\text { type }\end{array}$ \\
\hline $\begin{array}{c}\text { Functionality and } \\
\text { Parkinson's }\end{array}$ & $\begin{array}{c}\text { Describing the difficulties of occupational } \\
\text { performance of the subject with Parkinson's } \\
\text { disease. }\end{array}$ & $\begin{array}{c}\text { Cross-sectional } \\
\text { study }\end{array}$ \\
\hline $\begin{array}{c}\text { Functional Capacity } \\
\text { instrumental. }\end{array}$ & $\begin{array}{c}\text { Assessing the ability of elderly people to } \\
\text { perform the activities of daily living and }\end{array}$ & $\begin{array}{c}\text { Quantitative, } \\
\text { descriptive } \\
\text { approach }\end{array}$ \\
\hline
\end{tabular}

Table 2. Distribution of articles categorized according to: Theme, Goal and Methodology. Joao Pessoa PB, 2011.

\begin{tabular}{|c|c|c|}
\hline Theme & $\begin{array}{r}\text { Objective } \\
\end{array}$ & Methodology \\
\hline $\begin{array}{c}\text { Elderly Institutionalized and } \\
\text { everyday activities }\end{array}$ & $\begin{array}{l}\text { Assessing the factors associated } \\
\text { with changes in gait speed and } \\
\text { grip force manual in } \\
\text { institutionalized elderly. }\end{array}$ & Cross-sectional study \\
\hline $\begin{array}{l}\text { Functional assessment and } \\
\text { health promotion }\end{array}$ & $\begin{array}{l}\text { Developing a functional health } \\
\text { tracking strategy of seniors } \\
\text { from the community and } \\
\text { subsequent targeting to } \\
\text { preexisting health resources. }\end{array}$ & Prospective cohort \\
\hline $\begin{array}{l}\text { Institutionalization and } \\
\text { Functional Decline }\end{array}$ & $\begin{array}{l}\text { Reporting the clinical and } \\
\text { functional evolution of an } \\
\text { elderly resident in (ILPI) }\end{array}$ & Case Studies \\
\hline Functionality & $\begin{array}{l}\text { Tracing the history of } \\
\text { development, evolution and } \\
\text { correct use of the Index of } \\
\text { Independence in activities of } \\
\text { daily living of Katz, as well as } \\
\text { modifications and adaptations } \\
\text { developed. }\end{array}$ & Bibliography \\
\hline $\begin{array}{c}\text { Polypharmacy and } \\
\text { institutionalization versus } \\
\text { Low Functionality }\end{array}$ & $\begin{array}{l}\text { Assessing the factors associated } \\
\text { with the presence of } \\
\text { polypharmacy in elderly } \\
\text { patients admitted to ILP. }\end{array}$ & $\begin{array}{l}\text { Cross-sectional study, } \\
\text { retrospective }\end{array}$ \\
\hline $\begin{array}{c}\text { Functionality and family } \\
\text { environment }\end{array}$ & $\begin{array}{c}\text { Analyze the relationship } \\
\text { between family functionality } \\
\text { and the functional capacity of } \\
\text { the elderly dependents. }\end{array}$ & Cross-sectional study \\
\hline
\end{tabular}

The functional capacity of the elderly, including the ability to performing physical tasks, the preservation of mental activities, and an appropriate situation before the social 
integration. ${ }^{13}$ Thus, the functional assessment seeks to ascertain to what level the diseases or injuries impede the performance of daily activities the elderly autonomously and independently, allowing the development of a more appropriate care planning. It is a parameter, associated with other health indicators, can be used to determine the effectiveness and efficiency of the proposed interventions. ${ }^{14}$

It reveals itself as a crucial reality from a higher concentration of publishing in the Southeast. Which is justified as a region that concentrates the largest urbanized and industrialized centers in the country, containing a proportion of elderly above the national average, beyond the centers of biomedical research and health also publishes concentrate in southeastern Brazil arousing greater interest of scholars healthcare. ${ }^{15}$ Leaving explicit the need for advances in research in the North, Northeast and Center-West regarding the theme functionality in the elderly.

Of the thirteen selected articles with publication year between 2001 and 2011, we had seven studies published in 2010, two in 2007, 2009 and 2011. The results show that the subject Functional Capacity has recently aroused great interest from researchers in the area of health. Studies emphasize that the adoption of the Statute of the Elderly in Brazil, in September 2003, followed by the National Health Policy for Older Persons (PNSPI), passed in 2006, which has as its central focus the promotion of healthy aging and the maintenance of maximum capacity functional, are milestones that drove the study in this area. ${ }^{16,17}$

Among the areas of professional practice, physiotherapy had $38.46 \%$ of the publications of our sample, $23,07 \%$ of the articles are part of the field of Nursing and Gerontology/Geriatrics, 7,7\% belongs to the area of Physical Education and Occupational Therapy. As health professionals, we often act against the elderly in hospitals, clinics at the basic, long-term care facilities and elderly groups, making it imperative the need for health professionals to expand their knowledge on functional capacity through interdisciplinary research. ${ }^{18,19}$ Thus it confirms that both the healthcare context as in scientific functional capacity is inter and multidisciplinary.

It notices in the computation of the work presented here, that the issues that had been the most prominent feature, functional capacity and institutionalization; while the most frequent objectives were to evaluating and/or verifying $(46,15 \%)$, be the functional capacity and physical performance of the elderly. A recent research review of studies on aging highlighted that health was the most discussed topic; there is still a portion of options to be explored within the subject functional capacity. ${ }^{16}$

Regarding the type of study, $53,84 \%$ are cross-sectional; it is appropriate to describing characteristics of populations with respect to certain variables and their distribution patterns. A cross-sectional survey may be of incidence and prevalence. The first investigates certain disease in groups of new cases. It is dynamic because fluctuates over time and in different spaces. A prevalence study of old and new in a nosology in a particular place and time instances, is static and essentially transverse. ${ }^{20,21}$ 


\section{CONCLUSION}

For the characterization of the reports analyzed, we consider that the Brazilian articles on health that punctuate the Functional Capacity in Elderly in daily activities demonstrate that this field is not yet saturated.

Functional capacity, therefore, emerges as a new paradigm of health, particularly relevant for determining the quality of life of the elderly. However, in view of the condition of health, work and the quality of life are underexplored studies with the elderly in their socio-interactional context.

Facing this fact, we suggested to health professionals that prioritize research involving this theme in various regions of the country to contribute to the diversification of the population studied. We also highlight the importance of interdisciplinary studies, since the aging process is multisystem.

\section{REFERENCES}

1. World Health Organization. Envelhecimento ativo: uma política de saúde. Brasília: Organização Pan-Americana da Saúde. 60p. [online] 2005. Disponível em:http://bvsms.saude.gov.br/bvs/publicacoes/envelhecimento_ativo.pdf

2. Nogueira SL, Ribeiro RCL, Rosado LEFPL, Franceschini SCC, Ribeiro AQ, Pereira ET. Fatores determinantes da capacidade funcional em idosos longevos. Rev. bras. fisioter. [online]. 2010, [Citado em 13 maio 2012]; 14 (4): 322-329. Disponível em: http: / / www.scielo.br/scielo.php?script=sci_arttext\&pid=\$1413-35552010000400009

3. Neri AL. Qualidade de vida na velhice e subjetividade. Qualidade de vida na velhice: enfoque multidisciplinar. Campinas: Alínea, 2007.

4. Ferreira OGL, Maciel SC, Silva AO, Sá RCN da, Moreira MASP. Significados atribuídos ao envelhecimento. Psico-USF. [online]. 2010 [citado em 11 dezembro 2012], 15(3): 357-364. Disponível em: http://www.scielo.br/pdf/pusf/v15n3/v15n3a09.pdf

5. Risman A. Envelhecimento: um processo multideterminado e multideterminante? Rev.Portal Divulg. [online]. 2010 [citado em 16 Março 2012];1 (26). Disponível em: http://www.portaldoenvelhecimento.org.br/revista/index.php

6. Alves LC, Leimann BCQ, Vasconcelos MEL, Carvalho MSC, Godo AG, Fonseca TCO, et al. Influência das Doenças Crônicas na Capacidade Funcional de Idosos. Cad. Saúde Pública. [online]. 2007, [citato em agosto, 2007]; 23(8):1924-1930. Disponível em:http://www.scielo.br/pdf/\%0D/csp/v23n8/19.pdf

7. Duarte YAO, Andrade CL, Lebrão ML. O Índex de Katz na avaliação da funcionalidade dos idosos. Rev.Esc Enferm Usp. [online]. 2007 [citado em 28 de maio 2012]; 41(2): 317-25. Disponível em: http://www.scielo.br/pdf/reeusp/v41n2/20.pdf 
8. Costa EC, Nakatani AYK, Bachion MM. Capacidade de Idosos da Comunidade para desenvolver Atividade de Vida Diária e Atividades Instrumentais da Vida Diária. Acta Paul Enferm. [online]. 2006 [citado em 19 outubro 2012]; 19(1):43-35. Disponível em: http://www.scielo.br/pdf/ape/v19n1/a07v19n1.pdf

9. Sampaio RF, Mancini MC, Gonçalves GGP, Bittencourt NFN, Miranda AD, Fonseca ST. Aplicação da classificação internacional de funcionalidade, incapacidade e saúde (CIF) na prática clínica do fisioterapeuta. Rev. bras. fisioter. [online]. 2005 [citado em 19 de 2012]; 9(2):129-136. Disponível

em: http://www.crefito3.com.br/revista/rbf/05v9n2/pdf/129_136_cif.pdf

10. Bonardi G, Souza VBA, Moraes JFD. Incapacidade funcional e idosos: um desafio para os profissionais de saúde. Sci med. [online]. 2007 [citado julho 2012]; 17(3):138-44. Disponível em:http://revistaseletronicas.pucrs.br/ojs/index.php/scientiamedica/article/viewDownloa dlnterstitial/1647/7873

11. Mendes KDS, Silveira RCCP, Galvão CM. Revisão integrativa: método de pesquisa para a incorporação de evidências na saúde e na enfermagem. Texto contexto - enferm. [online]. 2008 [citado março 2012]; 17(4):758-764. Disponível em: http://www.scielo.br/scielo.php?script=sci_arttext\&pid=\$0104-07072008000400018

12. Lima TAS, Menezes TMO. Produção do conhecimento sobre idosos e centros de convivência. Rev enferm UFPE. [on line]. 2012 [citado 16 março 2012];6(10):2505 Disponível em: http:// www.ufpe.br/revistaenfermagem/index.php/revista/article/4586

13. Montenegro SMRS, Silva CAB da. Os Efeitos de um Programa de Fisioterapia como Promotor de Saúde na Capacidade Funcional de Mulheres Idosas Institucionalizadas. Rev. Bras. Geriatr. Gerontol. [online]. 2007 [citado 17 outubro 2012]; 10(2): 161-178. Disponível em:http: //revista.unati.uerj.br/scielo.php?script=sci_arttext\&pid=\$18099823200700020000 3\&lng=pt.

14. Duarte YAO, Andrade CL, Lebrão ML. O Índex de Katz na avaliação da funcionalidade dos idosos. Rev. Esc. Enferm. Usp. [online]. 2007 [citado 28 abril 2012]; 41(2): 317-25. Disponível em: http://www.scielo.br/pdf/reeusp/v41n2/20.pdf

15. Barreto ML, Teixeira MG, Bastos FI, Ximenes RAA, Barata RB, Rodrigues LC. Sucessos e fracassos no controle de doenças infecciosas no Brasil: o contexto social e ambienteal, políticas, intervenções e necessidades de pesquisa. The Lancet. [online]. 2011 [citado 2 outubro 2012]; Disponível em: http://189.28.128.100/dab/docs/geral/the_lancet_05_2011.pdf

16. Bezerra FC, Almeida MI de, Therrien SMN. Estudos sobre envelhecimento no Brasil: revisão bibliográfica. Rev. Bras. Geritr. Gerontol. [online]. 2012 [citado 2 outubro 2012]; 15(1):155-167. Disponível em: http://www.scielo.br/pdf/rbgg/v15n1/17.pdf

17. Brasil. Ministério da Saúde. Portaria $n^{\circ} 2.528$ de 19 de Outubro de 2006. Aprova a Política Nacional de Saúde da Pessoa Idosa, 2006.

18. Rosa TEC, Benicio MHD, Latorre MRDO, Ramos LR. Fatores determinantes da capacidade funcional entre idosos. Rev Saúde Pública[online]. 2003 [citado 17 de novembro 2012]; 37(1):40-8. Disponível em: http://www.scielosp.org/pdf/rsp/v37n1/13543.pdf

Estudo transversal e/ou longitudinal. Rev. Para. Med. [online]. 2006 [citado em 09 Abril 2012]; 20(4): 5-5. Disponível em: 
http: / /scielo.iec.pa.gov.br/scielo.php?script=sci_arttext\&pid=S0101-

$59072006000400001 \&$ lng $=p t$

19. Nakatani AYK, Silva LB, Bachion MM, Nunes DP. Capacidade funcional em idosos na comunidade e propostas de intervenções pela equipe de saúde. Rev. Eletr. Enf. [online]. 2009 [citado em 3 de agosto 2012]; 11(1):144-50. Disponível em: http://www.fen.ufg.br/revista/v11/n1/v11n1a18.htm

20. Cano, MAT.; Ferriani, M das GC; Alves, AC; Nakata, CY. A produção do conhecimento sobre adolescência na enfermagem: período 1983 a 1996. Rev.latino-am.enfermagem, [online]. 1998 [citado em 10 janeiro 2012]; 6(1): 91-97. Disponível em: http://www.scielo.br/pdf/rlae/v6n1/13925.pdf 